\title{
IN VITRO ANTIVIRAL AND ANTIOXIDANT ACTIVITIES OF SILYMARIN AND PANAX GINSENG ON VERO CELLS INFECTED WITH BOVINE EPHEMERAL FEVER VIRUS AND BLUETONGUE VIRUS
}

\author{
BURAK DIK ${ }^{1 *}$, OGUZHAN AVCI ${ }^{2}$ and IRMAK DIK ${ }^{2}$ \\ 'Department of Pharmacology and Toxicology, Veterinary Medicine Faculty, \\ University of Selcuk, Konya, Turkey \\ ${ }^{2}$ Department of Virology, Veterinary Medicine Faculty, University of Selcuk, Konya, Turkey

\begin{abstract}
The inadequacy of antiviral drugs in the treatment of viral diseases, has led to herbal medicine. It was aimed to determine the antiviral and antioxidant activities of Silymarin and Panax ginseng against Bovine ephemeral fever virus (BEFV) and Bluetongue virus (BTV) in permanent cell culture. Silymarin and Panax ginseng were dissolved at the concentration of $400 \mu \mathrm{g} / \mathrm{mL}$ within distilled water. The cell proliferation test was used to evaluate the cytotoxic activity of the Silymarin and Panax ginseng. They were cytotoxic over $50 \mu \mathrm{g} / \mathrm{mL}$ dose in Vero cells. Hence, antiviral activities of subjects were investigated against BEFV at the 25 and 50 $\mu \mathrm{g} / \mathrm{mL}$ doses. However, they did not show antiviral activity at any dose level against BTV. Effects of Silymarin and Panax ginseng were evaluated on the total antioxidant capacity (TAC) and thiobarbituric acid reactive substances (TBARS), oxidative stress marker, levels in Vero cells infected with BEFV and BTV. Silymarin (25 and $50 \mu \mathrm{g} / \mathrm{mL}$ ) affected TAC levels in Vero cells infected with BEFV, but it did not effect the TBARS levels in Vero cells infected with BEFV and BTV. Panax ginseng decreased TBARS levels in both diseases, although it did not change TAC levels at same doses on Vero cells infected with BEFV and BTV. In conclusion, it is referred that Silymarin and Panax ginseng may have antiviral some viruses and they may have antioxidant, cell protective and inhibitory effects of virus replication.
\end{abstract}

Keyword: Antiviral, Bluetongue virus, Bovine ephemeral fever virus, Panax ginseng, Silymarin

Bovine ephemeral fever virus (BEFV) is a Rhabdovirus which has been classified as the genus Ephemerovirus. BEFV is an important virus for cattle and buffaloes. It may cause reduction of milk production, infertility and it has high morbidity and mortality. It seems as epizootic in tropic and subtropical regions of the world. The most important symptoms of the disease are vascular disorders, fever, leucopoenia, relative neutrophilia, elevated plasma fibrinogen and cytokines levels $(1,2)$.

Bluetongue virus (BTV) is in the Orbivirus genus and Reoviridae family (3). Though it causes bluetongue disease in ruminants worldwide, it is more common in Southern Europe and Mediterranean (4, 5). All ruminants are carriers of the disease and especially sheep have high morbidity rate and the disease causes economic loss $(4,6)$. The most prominent clinical signs are fever, hyperptyalism, hyperaemia, oedema, nasal discharge, and ulceration of the oral mucosa (5). While cattle have a low yield and they often do not show clinical signs (7).
Viruses are intracellular agents and they use the host cells to multiply. The treatments of viral diseases are difficult because the clinical symptoms are late, and they place into cells. The inadequacy of antiviral drugs has forced people to discover new herbal agents $(8,9)$, because antiviral therapy may be insufficient (10).

Medicinal plants have been widely used for the treatment of many diseases $(8,9,11)$. These herbs have a wide variety of active phytochemicals, including the flavonoids, saponins, terpenoids, polyphenolics and some vitamins (9). Many of these phytochemicals have antiviral effects either inhibiting the activity of viral replication or the formation of viral DNA or RNA. Antiviral effects of plants are needed because antiviral drugs are not effective enough and the presence of resistant viral strains (12).

Panax ginseng contains pharmacologically active ingredients (Ginseng saponins, ginsenosides, phenol compounds, acid polysaccharides and polyethylene compounds), has been used for many years

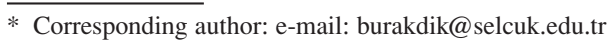


in medicine (13). It has cell protective (14) immunomodulatory, anti-inflammatory (15), antifungal, antiviral (16) and antioxidant effects (17). Chronic treatment with Panax ginseng has no toxic effects in rats, mice, dogs, and rabbits (14). Panax ginseng increase natural killer $(\mathrm{NK})$ cells and its activity $(18,19)$, stimulate nitric oxide synthesis in macrophage cell line (20) and decrease toll-like receptor (TLR) ligand-induced activation of dendritic cells (21).

Silymarin is obtained from Silybum marianum (milk thistle) plant and it contains flavonolignans, flavonoids, fatty acids, and other polyphenolic compounds. It has active components such as silybin A, silybin $\mathrm{B}$, isosilybin $\mathrm{A}$, and isosilybin $\mathrm{B}(22,23)$. It is used as a general medicinal herb and its effects are defined as, antifibrotic, anti-inflammatory, liver regenerating, immunomodulatory, anti-lipid peroxidative, antioxidant (24), hepatoprotective (25), antibacterial and antiviral (11).

Silymarin and Panax ginseng have polyphenolic compounds $(17,26)$. Flavonoids which are polyphenolic compounds have different biological properties including antimicrobial, antiviral, antiinflammatory and anti-allergic activity (27).
Silymarin is reported to inhibit RNA synthesis, viral protein expression, viral replication and blocking of the virus cell-to-cell spread (28). Antiviral mechanism of Panax ginseng may be related to preventive to reverse transcriptase, direct inhibition viral particles or host cell immunity enhancement (29) and maintaining the cell viability in case of viral infection-induced stress (30).

At the same time, lipid peroxidation biomarkers may be useful in the pathogenesis of viral infections (31). In addition, lipid peroxidation may play a role in the pathogenesis of viral diseases and antioxidant applications may be beneficial (32).

It has been hypothesized that Silymarin and Panax ginseng may increase their medical field as antiviral and antioxidant. The aim of this study was to determine the antiviral and antioxidant effects of Silymarin and Panax ginseng against BEFV and $\mathrm{BTV}$ in vitro.

\section{EXPERIMENTAL}

Vero permanent cell line (African green monkey kidney), BEFV and BTV were supplied from the store of Virology Department, Faculty of

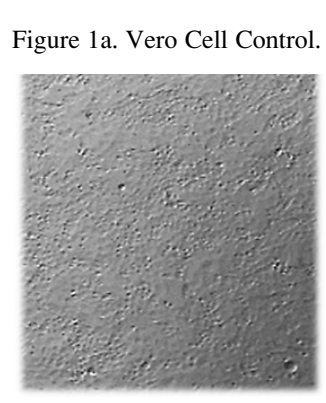

Figure 1b. Cytopathologic effect of BEFV.

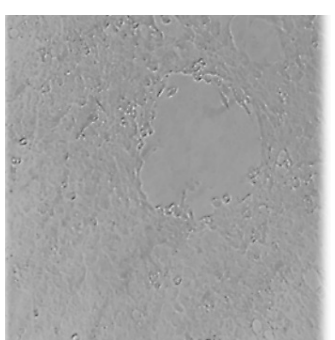

Figure 1c. Antiviral effects of Silymarin against BEFV.

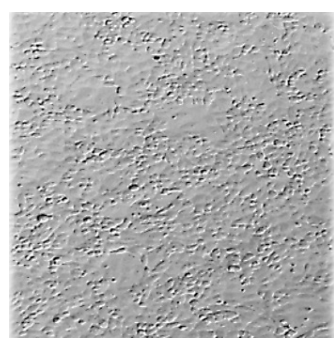

Figure 1d. Antiviral effects of Panax Ginseng against BEFV.

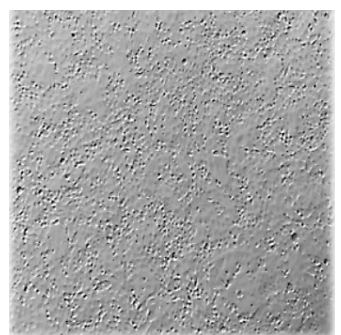

Figure 1. Cytopathologic and Antiviral effects of Silymarin against BEFV on Vero cell line (x40)

Figure 2a. Vero Cell control.

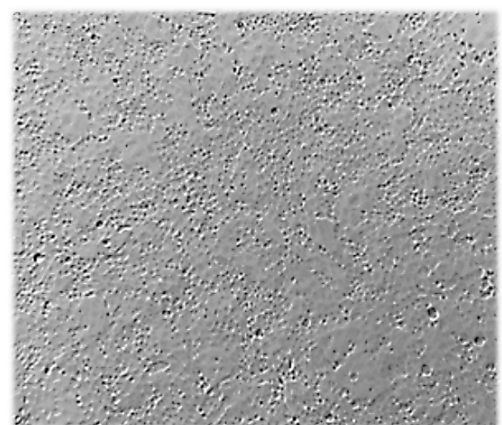

Figure 2b. Cytopathologic effect of BTV on Vero Cell Line.

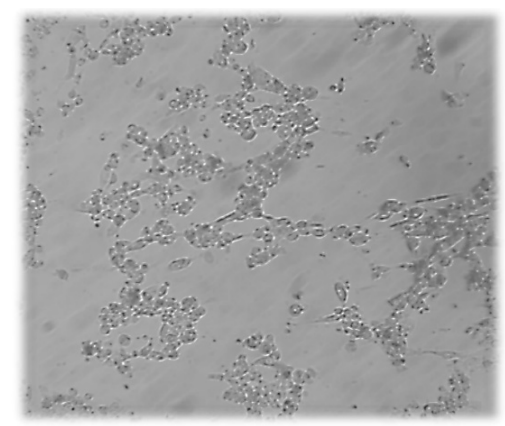

Figure 2. Cytopathologic effects of Silymarin against BTV on Vero cell line $(\times 40)$ 


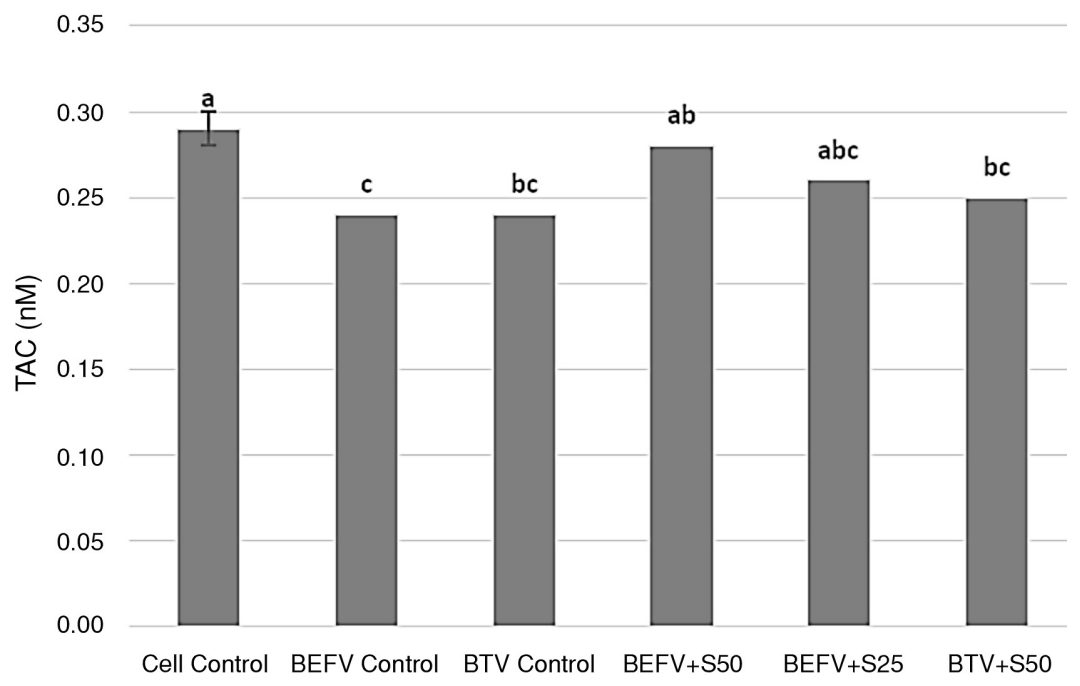

Figure 3. Effects of Silymarin Extract on TAC Level on Vero Cells infected with BEFV and BTV

TAC: Total Antioxidant Capacity. BEFV: Bovine ephemeral fever virus, BTV: Bluetongue virus, S50: 50 $\mu \mathrm{g} / \mathrm{mL}$ Silymarin extract, S25: $25 \mu \mathrm{g} / \mathrm{mL}$ Silymarin extract. a, b, c: Different letters are statistically significant $(\mathrm{p}<0.05)$

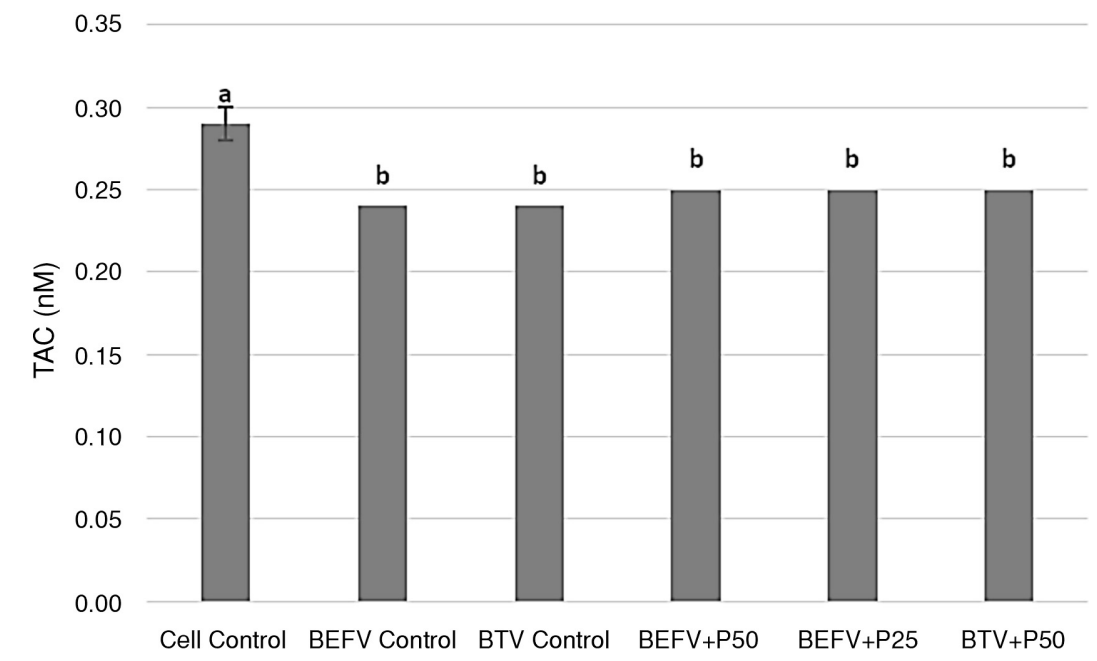

Figure 4. Effects of Panax ginseng Extract on TAC Level on Vero Cells infected with BEFV and BTV

TAC: Total Antioxidant Capacity, BEFV: Bovine ephemeral fever virus, BTV: Bluetongue virus, P50: $50 \mu \mathrm{g} / \mathrm{mL}$ Panax ginseng extract, P25: $25 \mu \mathrm{g} / \mathrm{mL}$ Panax ginseng extract. a, b: Different letters are statistically significant $(\mathrm{p}<0.05)$

Veterinary, University of Selcuk. The cells were cultivated in Dulbecco's Modified Eagle Medium (DMEM, Biological Industries, Kibbutz BeitHaemek, Israel) supplemented with 5\% heat-inactivated fetal bovine serum (FBS, Biological Industries, Kibbutz Beit-Haemek), and 1\% antibi- otics (10000 IU/mL penicillin G, $10 \mathrm{mg} / \mathrm{mL}$ streptomycin, Biological Industries, Kibbutz BeitHaemek, Israel) in a humidified atmosphere of 5\% carbon dioxide $\left(\mathrm{CO}_{2}\right)$ at $37^{\circ} \mathrm{C}$. To determine the antiviral activity of Silymarin (Cat no. S0292, Sigma-Aldrich Co., St. Louis, MO 63103, USA) 
and Panax ginseng (Cat no. 05115001, SigmaAldrich Co., St. Louis, MO 63103, USA), against BEFV and BTV.

\section{Cytotoxicity}

Stock solution $(20 \mathrm{mg} / \mathrm{mL})$ of the Silymarin and Panax ginseng were prepared as $400 \mu \mathrm{g} / \mathrm{mL}$ by diluting with ultra-pure water. Two-fold dilutions $(400-0.9 \mu \mathrm{g} / \mathrm{mL})$ of these medical extracts were placed in microplate wells and incubated in $5 \%$ $\mathrm{CO}_{2}$ at $37^{\circ} \mathrm{C}$ for $48 \mathrm{~h}$. After the incubation period, the non-toxic concentration of the extracts was determined for cells and also compared with untreated cells.

250

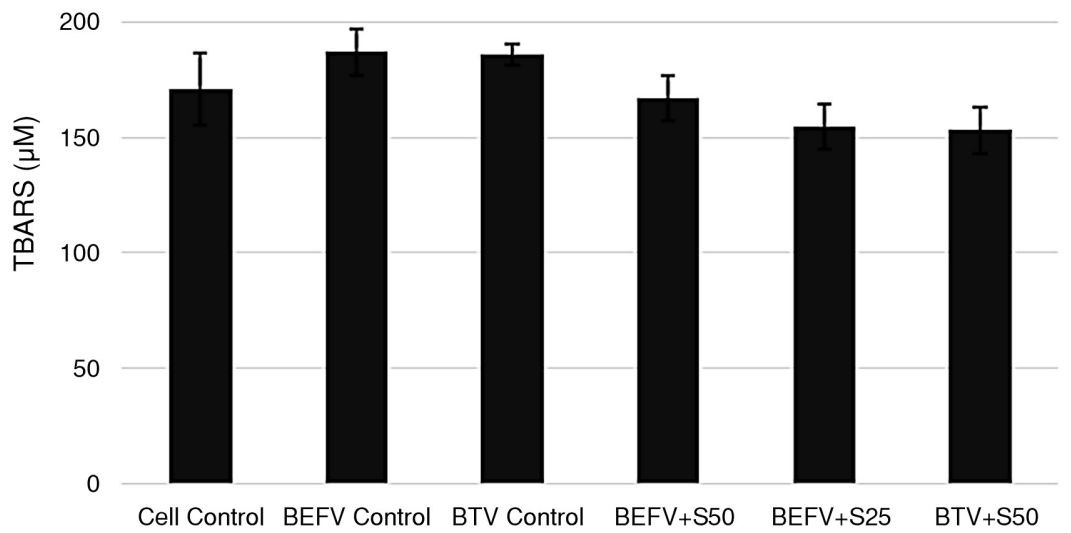

Figure 5. Effects of Silymarin Extract on TBARS Level on Vero Cells infected with BEFV and BTV

TBARS: Thiobarbituric acid reactive substances, BEFV: Bovine ephemeral fever virus, BTV: Bluetongue virus, S50: $50 \mathrm{\mu g} / \mathrm{mL}$ Silymarin extract, S25: $25 \mu \mathrm{g} / \mathrm{mL}$ Silymarin extract. There is no statistical difference between the groups $(p>0.05)$

250

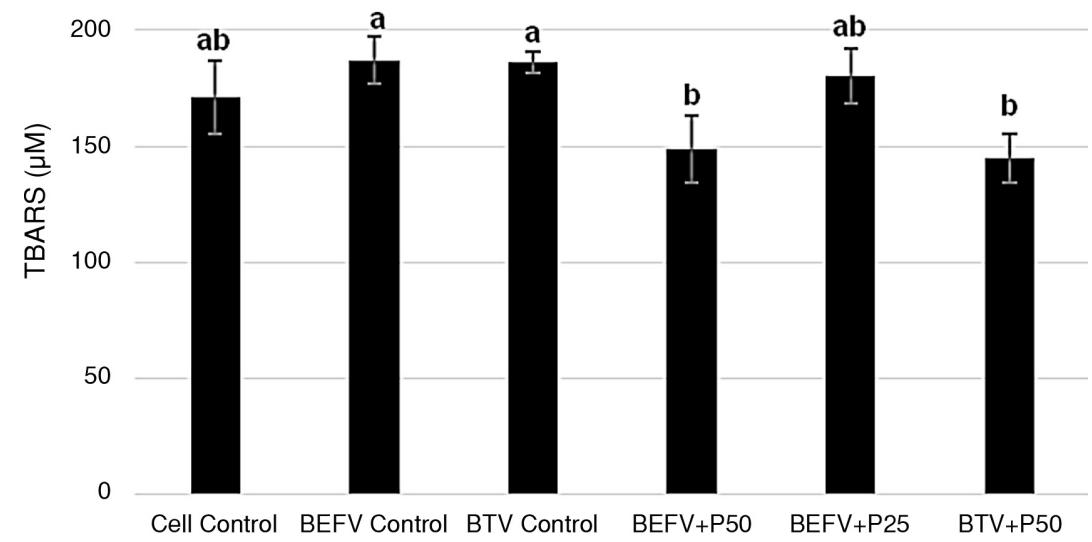

Figure 6. Effects of Panax Ginseng Extract on TBARS Level on Vero Cells infected with BEFV and BTV

TBARS: Thiobarbituric acid reactive substances, BEFV: Bovine ephemeral fever virus, BTV: Bluetongue virus, P50: 50 $\mu \mathrm{g} / \mathrm{mL}$ Panax ginseng extract, P25: $25 \mu \mathrm{g} / \mathrm{mL}$ Panax ginseng extract. a, b: Different letters are statistically significant $(\mathrm{p}<0.05)$ 
Cytotoxic effect was determined with commercially available test (Cell Proliferation Kit I, MTT, Cat. No. 11465007001, Roche, Mannheim, Germany) and applied as according to the procedure.

\section{Determination of antiviral activity}

Virus control, cell control, Silymarin and $\mathrm{Pa}$ nax ginseng extracts control were performed using by 96 well microplates (Corning, NY 14831, USA) with 8 wells for each control. BEFV and BTV [50\% tissue culture infectious dose $\left./ \mathrm{mL}\left(\mathrm{TCID}_{50} / \mathrm{mL}\right)\right]$ were inoculated. After maximum non-toxic doses of Silymarin and Panax ginseng extracts $(50 \mu \mathrm{g} / \mathrm{mL})$ were added into microplates wells and performed two-fold dilutions of the compounds. They were incubated with BEFV and BTV in $5 \% \mathrm{CO}_{2}$ at $37^{\circ} \mathrm{C}$ for $2 \mathrm{~h}$ in microplates wells. After incubation, $50 \mu \mathrm{L}$ of the cell suspension of 200.000 cells/ mL was placed briefly in each of 96 well microplates and they were incubated at $37^{\circ} \mathrm{C}$ in $5 \% \mathrm{CO}_{2}$ for $24 \mathrm{~h}$ to attach. The end of this period, the cells were analyzed using an inverted microscope for $\mathrm{CPE}$ by comparison with treated-untreated control wells. Hereby, antiviral activities of the extracts were detected in the non-CPE wells.

\section{Determination of oxidative stress and antioxidant effects}

Total antioxidant capacity (Antioxidant Assay Kit, Item no: 709001, Cayman Chemical Company, Michigan 48108, USA) and thiobarbituric acid reactive substances (TBARS) (TBARS Assay Kit, Item no: 10009055, Cayman Chemical Company, Michigan 48108, USA) levels of the wells in which the antiviral effect of the Silymarin and Panax ginseng extracts were determined in accordance with commercial Enzyme-Linked Immunosorbent Assay (ELISA) kits procedures. In addition, TBARS and Total Antioxidant Capacity (TAC) levels were determined in the wells that were the highest dose of antiviral activity of Silymarin and Panax ginseng.

\section{Statistical analysis}

The values were compared by ANOVA and Duncan test as posthoc (SPSS 22.0). Data are presented as mean \pm SEM. $\mathrm{p}<0.05$ level was accepted as statistically significance level.

\section{RESULTS}

Silymarin and Panax ginseng extracts were toxic to Vero permanent cells at a dose above 50 $\mu \mathrm{g} / \mathrm{mL}$ by MTT assay. Hereby, $50 \mu \mathrm{g} / \mathrm{mL}$ doses of Silymarin and Panax ginseng were determined as the maximum non-toxic dose. Doses of 25 and 50 $\mu \mathrm{g} / \mathrm{mL}$ of the Silymarin and Panax ginseng had the antiviral activity against BEFV (Fig. 1), while had no effecti on the BTV (Fig. 2).

Silymarin and Panax ginseng were evaluated for TAC and oxidative stress marker TBARS on Vero cells infective with BEFV and BTV. Silymarin increased TAC level at $50 \mu \mathrm{g} / \mathrm{mL}$ dose $(\mathrm{p}<0.05)$ on Vero cells infected with BEFV (Fig. 3). However, it didn't change TAC levels on Vero cells infected with BTV ( $p>0.05$, Fig. 3). As parallel, Panax ginseng didn't change TAC levels at all non-toxic dose levels on Vero cells infected with BEFV and BTV ( $p>0.05$, Fig. 4).

Although Silymarin changes the TAC levels, no dose did not change TBARS levels ( $p>0.05$, Fig. 5). But $50 \mu \mathrm{g} / \mathrm{mL}$ Panax ginseng decreased TBARS level on Vero cells infected with BEFV and BTV $(p<0.05$, Fig. 6).

\section{DISCUSSION}

The treatment of viral diseases is not sufficient, due to antiviral drugs are inadequate in veterinary medicine. Silymarin and Panax ginseng have been used in the treatment of various diseases for many years $(11,15)$. Some components of Silymarin (silybin and isosilybin) may be toxic to cells at high doses while other components (silychristin and silydianin) are not toxic. In addition, silymarin has a cytoprotective effect against free oxygen radical damage at normal doses for the cells (25). Silymarin plays a countervailing role and protects cells against many substances that induce oxidative stress because it acts against membrane lipid peroxidation. Silymarin provides antioxidant effect by decreasing malondialdehyde levels and regulating antioxidants such as catalase, superoxide dismutase, glutathione peroxidase and glutathione (33). In the present study, toxic compounds in the high doses of silymarin $(=100 \mu \mathrm{g} / \mathrm{mL})$ can be toxic on Vero cells. However, normal doses of silymarin may have inhibited that virus caused lipid peroxidation via increasing antioxidant enzymes.

Polyacetylene compounds of Panax ginseng have shown cytotoxic effects in some cell cultures such as MRC-5 and mesothelial cell culture, depending on the dose and time (34). Whereas, ginsenosides have antioxidant effects and cell protective by increasing nitric oxide level (14). Panax ginseng exhibits protective activity against chemicals on the liver by providing in vivo antioxidant properties (35). Panax ginseng protects against toxic substances in cells by free radical scavenging and inducing 
enzymes such as SOD and GPX (36). It has been reported to show antioxidant activity by reducing reactive oxygen species and malondialdehyde levels, increasing glutathione reductase levels and inhibiting DNA strand breakage $(37,38)$. In the current study, Panax ginseng may have shown toxic and antioxidant effects depending on the dose on Vero cell line. On the contrary, it may have increased nitric oxide levels and decreased oxidative stress by reducing malondialdehyde and free oxygen radicals.

Silymarin that contain silibinin molecules, provides antiviral effect in virus-infected cells by antioxidant effect and it depends an dose level. Silymarin is inherently difficult to resist because it contains different compounds. Its antiviral effect occurs by blocking virus replication (39). Silymarin acts antiviral effects through it induces the Janus kinase/signal transducers and activators of transcription pathway and activates interferon and other pathways. At the same time, Silymarin shows antiviral activity by either modulating cell membrane and membrane receptors or blocking NF-ęB and oxidative stress (40). Silymarin inhibits virus entry and virus transmission into the cell (28). Silymarin can produce an antiviral effect to protective effect on cell membranes and antioxidant effects. In addition, it may interfere with entry and infection of the virus into the cell through different pathways.

Active ingredients of Panax ginseng inhibit viral replication and adhesions dose-dependently (29). In addition, they exhibit antiviral activity by inhibiting certain metabolic enzymes (16) and increasing cell durability (30). Although the antiviral mechanism of Panax ginseng cannot be determined precisely, it has been detected dose-dependently antiviral activity against BEFV in the current study. This effect may be due to Panax ginseng promotes cell survival and inhibits viral replication.

\section{CONCLUSION}

Panax ginseng and Silymarin may have antiviral activities against some viruses because they have antioxidant, cell protective and inhibitory effects of virus replication. Although they can be considered as antiviral drugs for target diseases, extracts should be tested by in vivo researches.

\section{Acknowledgments}

A part of the abstract was presented at the "International Congress on Medicinal and Aromatic Plants" and the other part of the abstract was present at the " $2^{\text {nd }}$ International Congress on Advances in
Veterinary Sciences \& Technics (ICAVST)”.

\section{REFERENCES}

1. Walker P.J.: Curr. Top. Microbiol. Immunol. 292, 57 (2005).

2. Nandi S., Negi B.: Comp. Immunol Microbiol. Infect. Dis. 22, 81 (1999).

3. Arun S., John K., Ravishankar C., Mini M., Ravindran R., Prejit N.: Trop. Biomed. 31, 26 (2014).

4. Feenstra F., van Rijn P.A.: Crit. Rev. Microbiol. 43, 142 (2017).

5. Rushton J., Lyons N.: Vet. Ital. 51, 401 (2015).

6. Casaubon J., Chaignat V., Vogt H.R., Michel A.O., Thur B., Ryser-Degiorgis M.P.: BMC Vet. Res. 9, 166 (2013).

7. Katsoulos P.D., Giadinis N.D., Chaintoutis S.C., Dovas C.I., Kiossis E. et al.: Trop. Anim. Health Prod. 48, 469 (2016).

8. Avci O., Dik B.: Animal and Veterinary Sciences 2, 150 (2014).

9. Jassim S.A.A., Naji M.A.: J. Appl. Microbiol. 95, 412 (2003).

10. Clark M., Finkel R., Ray J.: Antiviral Drugs, in Pharmacology (Lippincott's Illustrated Reviews Series). Whalen K. Ed., pp.461-480, Lippincott Williams \& Wilkins, Philadelphia, 2012.

11. Ozcelik B., Kartal M., Orhan I.: Pharm. Biol. 49, 396 (2011).

12. Mukhtar M., Arshad M., Ahmad M., Pomerantz R.J., Wigdahl B., Parveen Z.: Virus Res. 131, 111 (2008).

13. Choi K.T.: Acta Pharmacol. Sin. 29, 1109 (2008).

14. Gillis C.N.: Biochem. Pharmacol. 54, 1 (1997).

15. Chong S., Oberholzer V.: Postgrad. Med. J. 64, 841 (1988).

16. Ng T.B., Wang H.: Life Sci. 68, 739 (2001).

17. Im Chung S., Kang M.Y., Lee S.C.: Prev. Nutr. Food Sci. 21, 24 (2016).

18. Miller S.C., Ti L., Shan J.: Immunol. Invest. 41, 157 (2012).

19. See D.M., Broumand N., Sahl L., Tilles J.G.: Immunopharmacology 35, 229 (1997).

20. Friedl R., Moeslinger T., Kopp B., Spieckermann P.G.: Br. J. Pharmacol 134, 1663 (2001).

21. Rhule A., Rase B., Smith J.R., Shepherd D.M.: J. Ethnopharmacol. 116, 179 (2008).

22. Lee D.Y., Liu Y.: J. Nat. Prod. 66, 1171 (2003).

23. Kim N.C., Graf T.N., Sparacino C.M., Wani M.C., Wall M.E.: Org. Biomol. Chem. 1, 1684 (2003).

24. Ghosh A., Ghosh T., Jain S.: J. Pharm. Sci. Technol. 2, 348 (2010). 
25. Dvorak Z., Kosina P., Walterova D., Simanek V., Bachleda P., Ulrichova J.: Toxicol. Lett. 137, 201 (2003).

26. Koksal E., Gulcin I., Beyza S., Sarikaya O., Bursal E.: J. Enzyme Inhib. Med. Chem. 24, 395 (2009).

27. Cushnie T.T., Lamb A.J.: Int. J. Antimicrob. Ag. 26, 343 (2005).

28. Wagoner J., Negash A., Kane O.J., Martinez L.E., Nahmias Y. et al.: Hepatology 51, 1912 (2010)

29. Lee M.H., Lee B.H., Jung J.Y., Cheon D.S., Kim K.T., Choi C.: J. Ginseng Res. 35, 429 (2011).

30. Yoo D.G., Kim M.C., Park M.K., Park K.M., Quan F.S. et al.: PLoS One. 7, e33678 (2012).

31. Raju T.A., Lakshmi A.N., Anand T., Rao L.V., Sharma G.: Asia Pac. J. Clin. Nutr. 9, 314 (2000).

32. Hennet T., Peterhans E., Stocker R.: J. Gen. Virol. 73, 39 (1992).
33. Kiruthiga P.V., Pandian S.K., Devi K.P.: Toxicol. App. Pharmacol. 247, 116 (2010).

34. Matsunaga H., Katano M., Yamamoto H., Fujito H., Mori M., Takata K.: Chem. Pharm. Bull. (Tokyo). 38, 3480 (1990).

35. Gum S.I., Jo S.J., Ahn S.H., Kim S.G., Kim J.T. et al.: J. Ethnopharmacol. 112, 568 (2007).

36. Abdel-Wahhab M.A., Ahmed H.H.: J. Ginseng Res. 28, 11 (2004).

37. Kim H.G., Yoo S.R., Park H.J., Lee N.H., Shin J.W. et al.: Food Chem. Toxicol. 49, 2229 (2011)

38. Kitts D.D., Wijewickreme A.N., Hu C.: Mol. Cell. Biochem. 203, 1 (2000).

39. Ahmed-Belkacem A., Ahnou N., Barbotte L., Wychowski C., Pallier C. et al.: Gastroenterology 138, 1112 (2010).

40. Polyak S.J., Morishima C., Shuhart M.C., Wang C.C., Liu Y., Lee D.Y.: Gastroenterology 132, 1925 (2007).

Received: 7.06. 2018 